\title{
The Analysis of Economic Effect of Railway Piggyback Transportation in China
}

\author{
Hengjian Wang \& Zuoyi Liu \\ School of Traffic and Transportation, Beijing Jiaotong University, Beijing 100044, China
}

\begin{abstract}
This paper analyzes the economic effect of railway piggyback transportation in China, comparing the cost between railway piggyback transportation and that of highway transportation. After calculating the cost of station to station railway piggyback transportation and that of highway freight transportation (taking Deppon logistics as an example) and comparing these two with the cost of logistics market in Beijing, it indicates that if the transportation price adopts 40 foot container of railway as station to station railway piggyback transportation, the transferring cost for per ton kilometer of packed computers and heavy goods are much economical than that of Deppon's and slightly lower than that of logistics market in Beijing for highway transportation. Therefore, introducing railway piggyback transportation in China is entirely feasible under a reasonable cost strategy.
\end{abstract}

KEYWORD: piggyback transportation; transportation; economic; feasibility; cost

\section{INTRODUCTION}

Piggyback transportation is an intermodal transportation method that placing a delivery vehicle in another carrier. Countries like America, Germany, French and Sweden, etc. adopt such transportation method and generate impressive economic and social benefits. Additionally, piggyback transportation is one of the intermodal and door to door transportation forms of developed countries in Europe and America (Chen Jingliang et al, 2016). It possesses a significant position in comprehensive transportation system; however, the railway piggyback transportation has not been introduced in China yet. After an intensive study of its feasibility and related technical requirements, it is believed that it is feasible to adopt piggyback transportation if vehicle type and transportation corridor are settled. As piggyback transportation is able to make up many disadvantages of road transportation (Wu Qiang, 2011), this paper is going to further analyze the economic effect of the former, under the current conditions for piggyback transportation.

\section{COMPARISON OF THE COST BETWEEN RAILWAY PIGGYBACK TRANSPORTATION AND ROAD TRANSPORTATION}

Railway piggyback transportation is a typical coordinated transport of road and railway. It includes road transportation in the ends and station to station railway transportation in between. Therefore, com- pared with road transportation, railway piggyback transportation distinguishes itself in the intermediate process. This also contributes to the difference between these two transportation methods. Given that, to study the cost of rail way piggyback transportation so as to propose a price strategy for rail way piggyback transportation, the following focuses on comparing the cost in the intermediate process.

\section{CALCULATION OF STATION TO STATION PRICE OF RAILWAY PIGGYBACK TRANSPORTATION}

Both railway piggyback transportation and container transportation target the high value added goods. The requirement of flatcars used for railway piggyback transportation to transfer a vehicle is the same for railway to transfer a 40 foot container. Additionally, the maximum load of vehicle for railway piggyback transportation has little difference of that for 40 foot container. Therefore, the cost for railway flatcar to transfer a 40 foot container is similarly equal to the cost for railway piggyback transportation to use a flatcar for station to station transportation. Under this, ton per kilometer cost for transferring freight which adopting railway piggyback transportation can be calculated.

To improve calculating accuracy, the following principles are adopted.

(1) Railway transportation cost includes: railway transport cost; cargo handling charges both at departure and arrival stations. 
(2) 60 ton railway flatcar as an example of railway flatcar.

(3) Calculate transportation cost of packed freight and heavy goods separately. Suppose heavy goods reach the tonnage capacity of highway vehicle; take desk -top computers as an example for packed goods (refer to Table.1 for size specification). Considering the weight and volume of freight and packing material, it is estimated that the volume of per packed computer is 0.12 cubic meters; weight, 25 kilograms.

Table.1 Specifications of Desk-Top Computer

\begin{tabular}{|l|l|l|l|l|}
\hline Compounds & Length(m) & Width(m) & High(m) & Volume(m3) \\
\hline Mainframe & $0.4 \mathrm{~m}$ & $0.17 \mathrm{~m}$ & $0.38 \mathrm{~m}$ & 0.026 \\
\hline $\begin{array}{l}\text { Display } \\
\text { Screen }\end{array}$ & $0.5 \mathrm{~m}$ & $0.06 \mathrm{~m}$ & $0.35 \mathrm{~m}$ & 0.011 \\
\hline Keyboard & $0.46 \mathrm{~m}$ & $0.16 \mathrm{~m}$ & $0.02 \mathrm{~m}$ & 0.001 \\
\hline $\begin{array}{l}\text { Total } \\
\text { Volume }\end{array}$ & - & - & - & 0.038 \\
\hline
\end{tabular}

(4) As for highway vehicle, it adopts van semitrailer and truck. For van semi-trailer, it adopts Dong Feng semi-trailer as an example with 30 tonnage capacity and $75 \mathrm{~m} 3$ loading capacity. For truck, it adopts Dong Feng truck with 20 tonnage capacity and $55 \mathrm{~m} 3$ loading capacity. Dong Feng semi-trailer is capable of carrying 625 packed computers with pay load capacity of 15.6 ton and 30 ton for heavy goods. Dong Feng truck is capable of loading 458 packed computers with pay load capacity of 11.5 ton and 20 ton for heavy goods.

Adopting 40 foot container transportation cost in railway transportation to simulate station to station transport cost in railway piggyback transportation, the station to station cost for railway piggyback in Beijing and other 14 provincial cities are listed in Table. 2 and the curve of unit cost (per ton kilometer, similarly hereinafter) is as below.

Table.2 Adopting 40 Foot Container Transport Cost in Railway Transportation to Simulate Station to Station Transport Cost in Railway Piggyback Transportation

\begin{tabular}{|c|c|c|c|c|c|c|}
\hline & \multirow{2}{*}{$\begin{array}{c}\text { Distanc- } \\
\mathrm{e}(\mathrm{km})\end{array}$} & \multirow{2}{*}{$\begin{array}{c}\text { Total } \\
\text { Cost } \\
\text { Departure-Arrival }\end{array}$} & $\begin{array}{c}\text { Packed Desk-Top Computers } \\
\text { Unit Cost( CNY/ ton-km) }\end{array}$ & \multicolumn{2}{|c|}{$\begin{array}{c}\text { Unit Cost for Heavy Goods } \\
\text { (CNY/ ton-km) }\end{array}$} \\
\cline { 5 - 7 } & & $\begin{array}{c}\text { Dong Feng } \\
\text { Semi-Trailer }\end{array}$ & $\begin{array}{c}\text { Dong Feng } \\
\text { Truck }\end{array}$ & $\begin{array}{c}\text { Dong Feng } \\
\text { Semi-Trailer }\end{array}$ & $\begin{array}{c}\text { Dong Feng } \\
\text { Truck }\end{array}$ \\
\hline East Beijing-East Jinan & 495 & 3697.70 & 0.48 & 0.65 & 0.25 & 0.37 \\
\hline East Beijing-East Taiyuan & 568 & 4029.70 & 0.45 & 0.62 & 0.24 & 0.35 \\
\hline East Beijing-East Shenyang & 741 & 4776.10 & 0.41 & 0.56 & 0.21 & 0.32 \\
\hline East Beijing-Changchun & 1034 & 6112.60 & 0.38 & 0.51 & 0.20 & 0.30 \\
\hline East Beijing-West Xian & 1169 & 6680.50 & 0.37 & 0.50 & 0.19 & 0.29 \\
\hline East Beijing-Harbin & 1288 & 7253.20 & 0.36 & 0.49 & 0.19 & 0.28 \\
\hline East Beijing-Northern Suburb & 1462 & 8094.60 & 0.35 & 0.48 & 0.18 & 0.28 \\
\hline East Beijing-North Lanzhou & 1609 & 10083.60 & 0.40 & 0.54 & 0.21 & 0.31 \\
\hline East Beijing-West Xining & 1826 & 11065.40 & 0.39 & 0.53 & 0.20 & 0.30 \\
\hline East Beijing-Chengdu & 2082 & 10814.20 & 0.33 & 0.45 & 0.17 & 0.26 \\
\hline East Beijing-South Guiyang & 2364 & 12250.00 & 0.33 & 0.45 & 0.17 & 0.26 \\
\hline East Beijing-Nanning & 2631 & 13373.40 & 0.33 & 0.44 & 0.17 & 0.25 \\
\hline East Beijing-East Kunming & 2993 & 15023.40 & 0.32 & 0.44 & 0.17 & 0.25 \\
\hline East Beijing-Urumqi & 3180 & 17024.10 & 0.34 & 0.47 & 0.18 & 0.27 \\
\hline Average & 1674 & 9305.61 & 0.37 & 0.51 & 0.20 & 0.29 \\
\hline
\end{tabular}

From Table.2, when adopting 40 foot container transport cost in railway transportation to simulate station to station transport cost in railway piggyback transportation, the unit cost of station to station transport will gradually decrease as transportation distance increases. Additionally, the unit cost of packed computers is higher than that of heavy goods. If it adopts piggyback transportation in Beijing and other 14 provincial cities in China, using Dong Feng semi-trailer and Dong Feng truck to transport packed computers separately, the average cost of per ton-km for Dong Feng semi-trailer is 0.37 RMB and for Dong Feng truck, 0.51 RMB; while using Dong Feng semi-trailer and Dong Feng truck to transfer heavy goods, the average cost of per ton kilometer is $0.20 \mathrm{RMB}$ and 0.29 RMB.

\section{CALCULATION OF ROAD TRANSPORTATION PRICE}

Currently, the transportation price of road transportation in China totally goes to marketization with various cost models. This paper refers to the transportation price used by the largest and most typical road logistic company in China-- Deppon Logistics Co., LTD (short for Deppon Logistics) and the price applied by Beijing logistic market for road transportation which is released by Beijing logistic public information platform so as to calculate road transportation cost in China.

(Liu Zuoyi et al, 2010) Transportation Cost via Deppon Logistics. 
Deppon Logistics is a 5A logistics enterprise with its main operation in road transportation service. Currently, the main transport products that Deppon provides include "Precision GPS-enabled Road Express Service”, "Precision Road Freight Service”, "Standard Express "and "Preferences for Freight of $3 \mathrm{~kg}-60 \mathrm{~kg}$ Service, etc. Considering the transport model of railway piggyback transportation and the freight it transports, this paper adopts the price of "Precision Road Freight Service" of Deppon Logistics as calculation basis.
Heavy goods, according to Deppon Logistic standard, is defined as that ratio of gross weight $(\mathrm{kg})$ and gross volume (m3) is greater than or equal to 210, and it is charged by weight ; while the ratio smaller than 210 is called light goods and it is charged by volume. In this paper, the weight of per packed computer is $25 \mathrm{~kg}$ with the volume of 0.12 $\mathrm{m} 3$, the ratio of weight and volume is 208 which belongs to light goods. Given that, the transportation cost via Deppon is showed in Table.3.

Table.3 Transportation Cost via Deppon Logistics

\begin{tabular}{|c|c|c|c|c|c|}
\hline \multirow{2}{*}{ Departure--Arrival } & \multirow{2}{*}{ Distance(km) } & \multicolumn{2}{|c|}{ Heavy Goods } & \multicolumn{2}{c|}{ Packed Desk-Top Computers } \\
\cline { 3 - 6 } & & $\begin{array}{c}\text { Unit Cost } \\
(\mathrm{CNY} / \mathrm{kg})\end{array}$ & $\begin{array}{c}\text { Unit Cost } \\
(\mathrm{CNY} / \mathrm{ton}-\mathrm{km}\end{array}$ & $\begin{array}{c}\text { Unit Cost } \\
(\mathrm{CNY} / \mathrm{m} 3)\end{array}$ & $\begin{array}{c}\text { Unit Cost } \\
(\mathrm{CNY} / \mathrm{ton}-\mathrm{km})\end{array}$ \\
\hline Beijing-Jinan & 495 & 1.40 & 2.83 & 294 & 2.85 \\
\hline Beijing-Taiyuan & 568 & 1.45 & 2.55 & 305 & 2.57 \\
\hline Beijing-Shenyang & 741 & 1.45 & 1.96 & 305 & 1.97 \\
\hline Beijing-Changchun & 1034 & 1.50 & 1.45 & 315 & 1.46 \\
\hline Beijing-Xian & 1169 & 2.15 & 1.84 & 452 & 1.85 \\
\hline Beijing-Harbin & 1288 & 1.50 & 1.16 & 315 & 1.17 \\
\hline Beijing-Shanghai & 1462 & 1.65 & 1.13 & 347 & \\
\hline Beijing-Lanzhou & 1609 & 2.25 & 1.40 & 473 & 1.14 \\
\hline Beijing-Xining & 1826 & 2.25 & 1.23 & 473 & 1.41 \\
\hline Beijing-Chengdu & 2082 & 2.52 & 1.21 & 530 & 1.24 \\
\hline Beijing-Guiyang & 2364 & 2.20 & 0.93 & 462 & 1.22 \\
\hline Beijing-Nanning & 2631 & 2.25 & 0.86 & 473 & 0.94 \\
\hline Beijing-Kunming & 2993 & 2.45 & 0.82 & 515 & 0.86 \\
\hline Beijing-Urumqi & 3180 & 3.25 & 1.02 & 683 & 0.82 \\
\hline Average & 1674 & 2.02 & 1.46 & 424 & 1.03 \\
\hline
\end{tabular}

From Table.3, generally, as transportation distance increases, the transportation price via Deppon Logistics gradually decreases with an obvious fluctuation. Additionally, the transportation price for heavy goods and packed computers are almost consistent to each other. The curve of these two shows a clear trend of overlapping. The average cost of per ton-km for heavy goods from Beijing to other 14 provincial cities under Deppon Logistics is 1.46 RMB and packed computers, 1.47 RMB.

(Liu Zuoyi et al, 2011) Road Transportation Price in Logistics Market in Beijing

The road transportation price in Beijing's logistics market is monitored by the Information Center of Beijing Logistics Association and released by Beijing logistics public information platform. As transportation distance increases, the transportation price of heavy goods and packed computers under logistics market price for road transportation in Beijing indicates a tender decrease and a relative large fluctuation. But altogether, the price for packed computers is higher than that of heavy goods. From Beijing to other14 provincial cities, the transportation price of heavy goods under road transportation in Beijing's logistics market is 0.39 RMB; packed computers, 0.52 RMB.

\section{COMPARATIVE ANALYSIS OF PRICE FOR PIGGYBACK TRANSPORTATION AND ROAD TRANSPORTATION}

From the analysis above, we've already known, from Beijing to other 14 provincial cities in China, the transportation price for piggyback transportation, adopting 40 foot container in railway transportation to simulate station to station cost, the price via Deppon Logistics and the price via road transportation in Beijing logistics market. After comparing the price for transporting packed computers and heavy goods, the station to station transportation price per ton-km for piggyback transportation, adopting 40 foot container in railway transportation for simulation, is much lower than that of Deppon as well as the price of road transportation in Beijing logistics market for heavy goods while the price for packed computers is no obvious difference with that of piggyback transportation. Therefore, the price for station to station transportation of piggyback transportation stands a certain advantage when compared with road transportation. 


\section{PRICE STRATEGY FOR RAILWAY PIGGYBACK TRANSPORTATION}

The purpose of introducing piggyback transportation in China is to ease the pressure of road transportation in long distance for multi variety, small quantity and high value added goods market. In early stage, it focuses on cultivating the market of piggyback transportation and gradually spreading the influence of it. Given that, in the prime stage of piggyback transportation in China, we can adopt penetration pricing strategy; that is using relative low price of piggyback transportation to enhance users' acceptance of it then to rapidly spread its market. Additionally, the price of newly added railway transportation for bulk goods and the price of express train transportation for freight which is implemented by railway administration are competition oriented. The price is mainly in accordance with the variable costs of goods and fully close to while slightly lower than the price of road transportation. Therefore, price strategy for railway piggyback transportation of its early stage in China will mainly adopt penetration pricing strategy as basis and will refer to current price applied in railway freight transportation. Under this, the main goal of piggyback transportation price is to cultivate its market and gradually spread the influence of it as well as to apply market competition as guideline so that the price of it can be more economical than that of road transportation.

\section{CONCLUSION}

As analyzed above, it can be known that when transporting packed computers and heavy goods, the station to station transportation price per ton-km of piggyback transportation, adopting 40 foot container in railway transportation for simulation, is much lower than that of Deppon and is slightly lower than that of road transportation in Beijing logistics market. Therefore, it is feasible to introduce piggyback transportation in the condition of adopting the price of 40 foot container in railway transportation to be as the price of station to station transportation for piggyback transportation and also using market competition as guideline to control the price that lower than that of road transportation.

\section{REFERENCES}

Chen Jingliang, Liu Zuoyi: Study on the Feasibility of Railway Piggyback Transportation in China [R].2016.

China Railway Corporation. Railway Technical Management Procedures (Common Speed Train) [M]. Beijing: China Railway Publishing House, 2014.

GB146.1-83, Rolling Stock Gauge for Standard Gauge Railways [S].
Liu Zuoyi, Lang Maoxiang: Railway Freight Transportation [M].Beijing: China Railway Publishing House, 2011

Liu Zuoyi, Zhao Yu, Su Shunhu: Transportation Marketing [M]: Beijing: China Railway Publishing House, 2010

Wu Qiang: Railway Container Transportation [M].Beijing: China Railway Publishing House, 2011 